Vol.5 No.2, Agustus 2020, pp. 121-131

ISSN: 2597-7156 (Online),2502-7786 (Print)

http://jurnal.uimedan.ac.id/index.php/JIPIKI

\title{
Sistem Antrian Rekam Medis Pasien Di Rumah Sakit Menggunakan Model Multi Channel Dengan Pola Poisson
}

\author{
Yeyi Gusla Nengsih \\ Program Studi D-III Perekam dan Informasi Kesehatan, Universitas Imelda Medan
}

\section{Article Info}

Article history:

Received July 31, 2020

Revised August 14, 2020

Accepted August 29, 2020

Keywords:

Queue

Medical Records

Poisson Pattern

\begin{abstract}
Queue is an occurrence where someone has to wait their turn to get service. Queuing processes in hospitals when processing outpatient registration medical records at the hospital often occur especially during peak hours. To overcome this problem, a solution is needed to improve service performance at the hospital. The queuing model used is the Multi Channel-single phase queuing model which has one or more services flowing by a single queue. The variables to be observed are time between arrivals, service time data and number of services assuming a Poisson distribution pattern. The results of this study will show the operator's busy time is $83.33 \%$, the number of queues in a certain period $(\mathrm{Lq})$ is 13 patients, the number of registrants in the system (L) is 14 patients, the waiting time in the queue (Wq) is 24 minutes, and waiting time in the system (W) is 30.06 minutes.
\end{abstract}

This is an open access article under the CC BY-SAlicense.

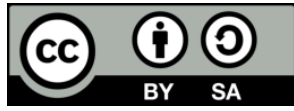

\section{Corresponding Author:}

Yeyi Gusla Nengsih,

Program Studi D-III Perekam dan Informasi Kesehatan,

Universitas Imelda Medan,

Jl. Bilal No. 52 Kelurahan Pulo Brayan Darat I Kecamatan Medan Timur, Medan - Sumatera Utara.

Email: yeyigusla22@gmail.com

\section{PENDAHULUAN}

Pelayanan ialah kegiatan yang mesti diperhatikan oleh suatu instansi agar kualitas pelayanan nya semakin baik. Pengertian pelayanan menurut undang-undang nomor 25 tahun 2009 pasal 1 adalah kegiatan dalam hal pemenuhan kebutuhan seseorang sesuai dengan peraturan perundang-undangan, selaku warga negara dan penduduk atas barang, jasa dan/atau pelayanan administratif yang telah diberikan oleh pemerintah penyelenggara dalam pelayanan publik. Apabila suatu pelayanan melihat acuan pada standarisasi yang telah ditetapkan yaitu undang-undang nomor 25 tahun 2009 pasal 1, maka masyarakat bisa menikmati manfaat pelayanan secara maksimal. Antrian ialah permasalahan yang sering terjadi dimana-dimana seperti dipom bensin, dibank, dibandara bahkan dirumah sakit.

Menurut penelitian (Nengsih, 2020) menyatakan hasil dari penelitian ini nantinya diperoleh waktu sibuk server terpanjang yaitu 94,12\%, jumlah rata-rata pasien dalam antrian terpanjang perperiode (Lq) yaitu 15 pasien, jumlah rata-rata pasien dalam sistem terpanjang perperiode (Ls) yaitu 16 pasien, waktu pasien berada dalam sistem terpanjang 
perperiode waktu (Ws) yaitu 60 menit, waktu pasien berada dalam antrian terpanjang perperiode waktu (Wq) yaitu 56,472 menit.

Sedangkan penelitian lain yang berkaitan dengan waktu tunggu pelayanan rekam medis di pendaftaran rawat jalan menyatakan hasil penelitian menunjukkan bahwa faktor yang sangat mempengaruhi waktu tunggu pelayanan rekam medis di pendaftaran rawat jalan RSUD Dr.R.M. Djoelham Binjai pada kegiatan rekam medis yaitu di penyimpanan. Pada Sumber Daya Manusia yaitu pendidikan dan pada Sumber Daya Material yaitu bahan dan fasilitas. Diperoleh rata-rata waktu tunggu untuk pasien baru yaitu 7 menit 27 detik dan rata - rata waktu tunggu pasien lama yaitu 14 menit 16 detik (M. Simanjuntak, 2016).

Menurut penelitian lain yang berjudul Pengaruh Waktu Tunggu Petugas Pelayanan Rekam Medis Terhadap Kepuasan Pasien menyatakan waktu tunggu pelayanan petugas rekam medis diperoleh bahwa yang tergolong kategori cepat terdapat 6 responden $(85,7 \%)$ dan yang tergolong lambat sebanyak 1 responden $(14,3 \%)$. Berdasarkan hasil pengolahan data maka hipotesis Ho ditolak dan Ha diterima sehingga terdapat pengaruh waktu tunggu pelayanan petugas rekam medis dengan kepuasan pasien di bagian pendaftaran rawat jalan di RSUD. R. M. Djoelham Binjai tahun 2015 (E. Simanjuntak, 2016).

Sistem antrian yang sering terjadi dirumah sakit adalah saat pasien harus melakukan pemeriksaan dan menjalani perawatan medis saat pendaftaran pada suatu instansi rumah sakit. Status kesehatan pasien tersebut akan dicatat oleh rekam medis untuk dijadikan sebagai acuan untuk pemeriksaan kesehatan selanjutnya. Saat ini banyak rumah sakit yang masih menerapkan sistem konvensional yaitu pencatatan arsip pasien yang dilakukan secara manual, sehingga membuat pasien menunggu sangat lama. Untuk mengatasi permasalahan ini dapat digunakan suatu model sistem antrian multi channel dengan pola poisson, walaupun secara langsung tidak dapat memecahkan masalah tetapi dapat mengambil tindakan ataupun keputusan untuk memprediksi antrian dirumah sakit dalam waktu jangka panjang.

\section{METODE PENELITIAN}

A. Disiplin Antrian

Disiplin antrian atau disiplin pelayanan adalah suatu aturan dimana customer memilih barisan antrian agar segera mendapatkan pelayanan dengan cepat pendapat yang dikemukakan oleh (Wereh H.S. et al, 2014). Adapun pembagian disiplin antrian antara lain:

1. First come first served (FCFS) atau first in first out (FIFO)

Suatu peraturan dimana pelanggan yang terlebih dahulu datang maka akan dilayani terlebih dahulu. Contohnya antri pembayaran di swalayan.

2. Last come first served (LCFS) atau last in first out (LIFO)

Suatu peraturan dimana pelanggan yang datang paling akhir akan dilayani paling awal. Contohnya sistem bongkar muat barang, pasien yang dalam kondisi kritis (darurat).

3. Service in random order (SIRO) atau random selection for services (RSS)

Suatu peraturan dimana pelayanan atau panggilan berdasarkan peluang secara random atau acak, jadi tidak dipermasalah siapa yang terlebih dahulu datang. Contohnya arisan berdasarkan nomor undian yang diambil secara acak.

4. Priority service (PS)

Suatu peraturan dimana lebih memprioritaskan pelanggan yang mempunyai prioritas lebih tinggi dibandingkan prioritas yang lebih rendah, meskipun prioritas lebih rendah ini lebih dahulu tiba dalam garis tunggu. Contohnya mempunyai hubungan kekerabatan maka potensial akan dilayani terlebih dahulu, seseorang yang memiliki penyakit lebih berat dibandingkan orang lain pada suatu tempat praktek dokter. 
B. Struktur Antrian

Struktur antrian terbagi dalam beberapa model antara lain sebagai berikut (Nurfitria D. et al, 2016):

1. Single Channel-Single Phase

Single Channel merupakan sistem pelayanan yang memiliki satu jalur atau satu pelayanan. Sedangkan Single phase adalah hanya memiliki satu stasiun pelayanan sehingga setelah menerima pelayanan dapat langsung keluar dari sistem antrian.

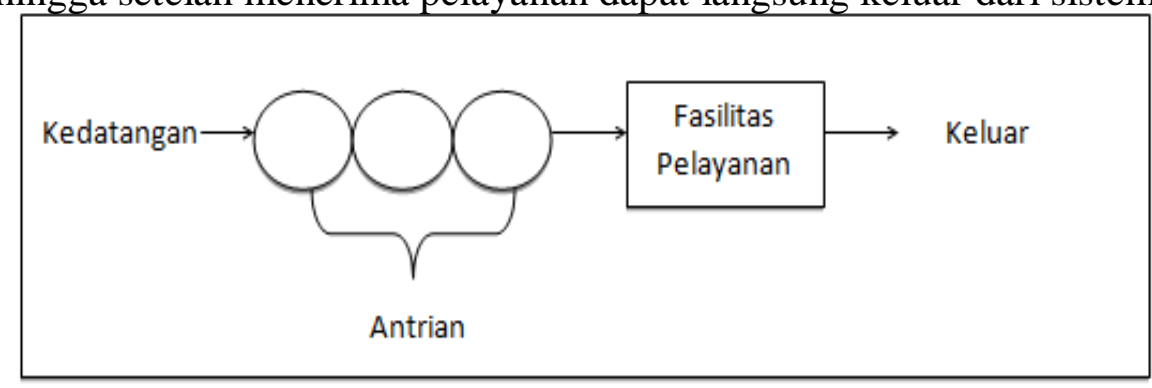

Gambar 1. Single Channel - Single Phase Service

2. Single Channel-Multi Phase

Single Channel Multi Phase atau jalur tunggal beberapa tahap pelayanan yaitu sistem antrian yang hanya ada satu jalur antrian namun ada dua atau lebih pelayanan yang dilaksanakan secara berurutan.

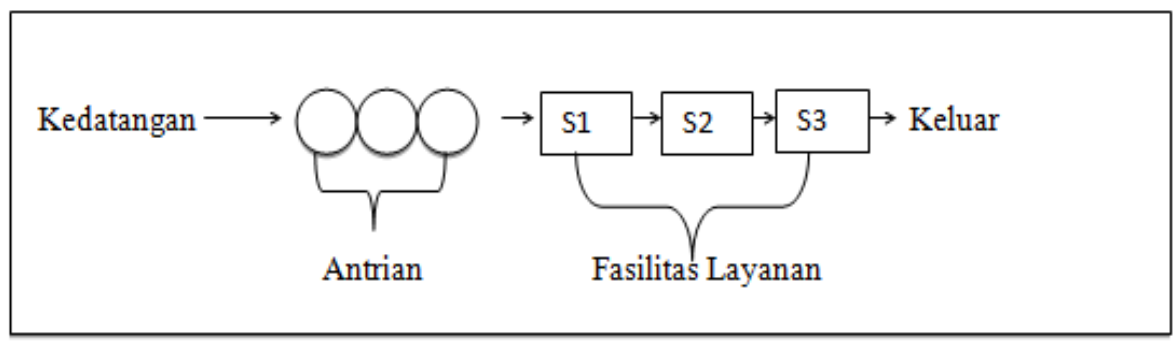

Gambar 2. Single Channel - Multi Phase Service

3. Multi Channel-Single Phase

Multiple Channel Single Phase atau jalur ganda satu tahap pelayanan yaitu sistem yang hanya terdapat satu jalur antrian dengan dua atau lebih fasilitas pelayanan.

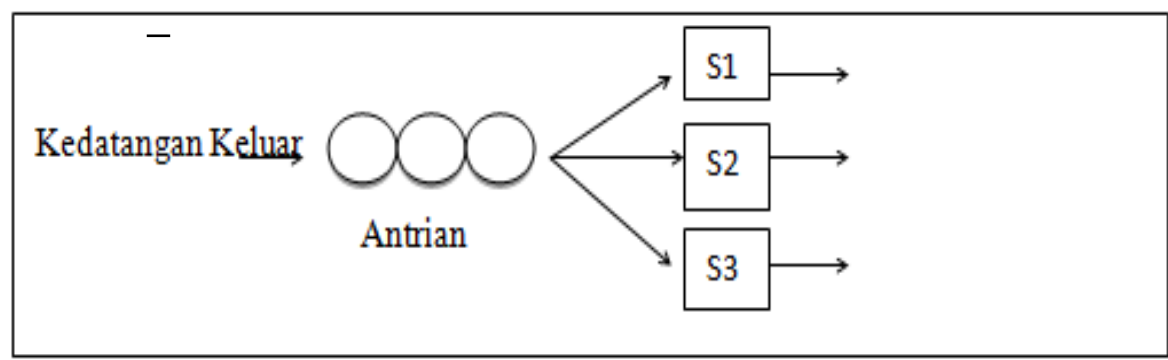

Gambar 3. Multi Channel - Single Phase Service

4. Multi Channel-Multi Phase

Multiple Channel Multi Phase atau jalur ganda beberapa tahap pelayanan yaitu sistem yang terdapat beberapa jalur antrian dengan beberapa tahap pelayanan. 


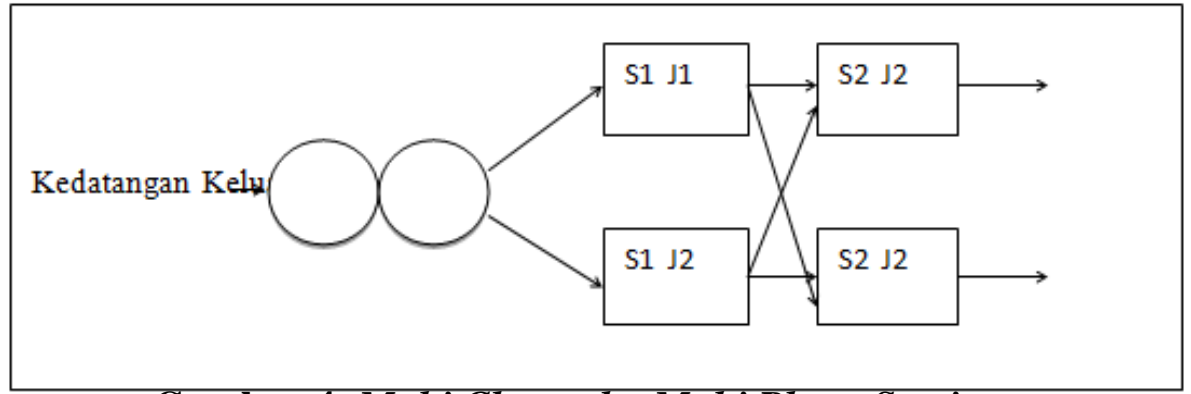

Gambar 4. Multi Channel -Multi Phase Service

C. Model Antrian

Untuk mengoptimalkan waktu pelayanan, kita dapat menentukan waktu pelayanan, jumlah saluran antrian, jumlah pelayanan yang tepat menggunakan model-model antrian. Ada empat model yang paling sering digunakan dapat dilihat pada tabel dibawah ini :

Tabel 1. Model Antrian

\begin{tabular}{|c|c|c|c|c|c|c|c|}
\hline$\overline{\text { Model }}$ & $\begin{array}{l}\text { Nama } \\
\text { Teknis } \\
\end{array}$ & Contoh & $\begin{array}{l}\text { Jumlah } \\
\text { Jalur }\end{array}$ & $\begin{array}{l}\text { Pola Tingkat } \\
\text { Kedatangan }\end{array}$ & $\begin{array}{c}\text { Waktu } \\
\text { Pelayanan } \\
\end{array}$ & $\begin{array}{l}\text { Ukuran } \\
\text { Antrian }\end{array}$ & Aturan \\
\hline A & $\begin{array}{l}\text { Sistem } \\
\text { sederhana } \\
(\mathrm{M} / \mathrm{M} / 1)\end{array}$ & $\begin{array}{l}\text { Meja } \\
\text { informasi di } \\
\text { departemen } \\
\text { store }\end{array}$ & Tunggal & Poisson & Eksponensial & $\begin{array}{l}\text { Tidak } \\
\text { terbatas }\end{array}$ & FIFO \\
\hline B & $\begin{array}{l}\text { Jalur } \\
\text { berganda } \\
(\mathrm{M} / \mathrm{M} / \mathrm{S})\end{array}$ & $\begin{array}{l}\text { Loket } \\
\text { penerbangan }\end{array}$ & Berganda & Poisson & Eksponensial & $\begin{array}{l}\text { Tidak } \\
\text { terbatas }\end{array}$ & FIFO \\
\hline $\bar{C}$ & $\begin{array}{c}\text { Pelayanar } \\
\text { konstan } \\
(\mathrm{M} / \mathrm{D} / \mathrm{I})\end{array}$ & $\begin{array}{l}\text { Tempat } \\
\text { pencucian } \\
\text { mobil } \\
\text { otomatis }\end{array}$ & Tunggal & Poisson & Konstan & $\begin{array}{l}\text { Tidak } \\
\text { terbatas }\end{array}$ & FIFO \\
\hline $\bar{D}$ & $\begin{array}{l}\text { Populasi } \\
\text { terbatas }\end{array}$ & $\begin{array}{l}\text { Bengkel } \\
\text { yang hanya } \\
\text { memiliki } \\
\text { selusin } \\
\text { mesin dapat } \\
\text { rusak }\end{array}$ & Tunggal & Poisson & Eksponensial & Terbatas & FIFO \\
\hline
\end{tabular}

\section{Model Antrian Multi Channel}

Persamaan yang digunakan dalam menganalisis antrian model antrian multi channel adalah sebagai berikut :

1. Probabilitas terdapat 0 pasien (tidak ada pasien dalam sistem)

$\mathrm{P} 0=1-\mathrm{P}$

2. Tingkat kesibukan server

$$
\mathrm{P}=\frac{\lambda}{\pi}
$$

3. Rata-Rata pasien dalam sistem

$$
\text { Ls }=\frac{p}{1-p}
$$

4. Rata-Rata pasien dalam antrian

$$
\mathrm{Lq}=\frac{\lambda}{\pi(\pi-\lambda)} 2
$$


5. Waktu yang dibutuhkan pasien dalam sistem

$$
\mathrm{Ws}=\frac{1}{\pi-\lambda}
$$

6. Waktu yang dibutuhkan pasien dalam antrian

$\mathrm{Wq}=\frac{\lambda}{\pi(\pi-\lambda)}$

\section{HASIL DAN PEMBAHASAN}

\subsection{Hasil}

Dari perhitungan maka diperoleh hasil kinerja analisis antrian model multi channel dengan pola poisson pada sistem antrian pendaftaran rekam medis dirumah sakit adalah sebagai berikut:

Tabel 2. Hasil Kinerja Sistem Antrian Rekam Medis Pada Rumah Sakit

\begin{tabular}{ccccccl}
\hline $\begin{array}{c}\text { Per } \\
\text { Waktu }\end{array}$ & \multicolumn{7}{c}{ Kinerja Sistem Antrian } \\
\cline { 2 - 7 } & $\mathrm{P}$ & $\mathrm{P} 0$ & $\mathrm{Ls}$ & $\mathrm{Lq}$ & $\mathrm{Ws}$ & $\mathrm{Wq}$ \\
\hline $09.00-09.59$ & 0,8182 & 0,1818 & 13,5456 & 11,0910 & 0,5016 & 0,4107 \\
\hline $10.00-10.59$ & 0,7917 & 0,2083 & 10,8594 & 8,4844 & 0,2857 & 0,2232 \\
\hline $11.00-11.59$ & 0,4583 & 0,5417 & 1,7416 & 0,3666 & 0,0527 & 0,0111 \\
\hline $08.00-08.59$ & 0,8333 & 0,1667 & 15,5208 & 13,0208 & 0,3104 & 0,2604 \\
\hline $09.00-09.59$ & 0,7867 & 0,2133 & 10,4382 & 8,0782 & 1,1769 & 0,1369 \\
\hline $10.00-10.59$ & 0,6667 & 0,3333 & 4,6666 & 2,6667 & 0,1555 & 0,0888 \\
\hline $11.00-11.59$ & 0,1852 & 0,8148 & 0,5620 & 0,0064 & 0,0562 & 0,0006 \\
\hline
\end{tabular}

Rangkaian percobaan dari hasil kinerja sistem antrian di atas dengan menggunakan perangkat lunak visual basic dapat dilihat pada gambar dibawah ini :

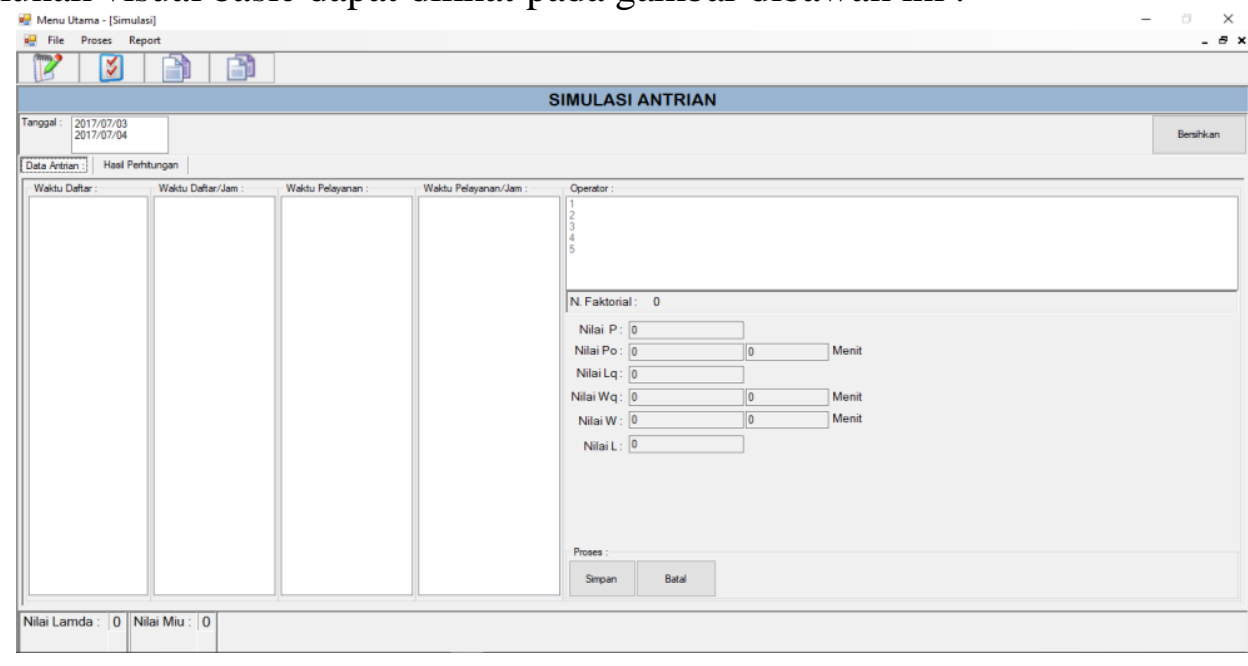

Gambar 5. Tampilan Menu Proses

\begin{tabular}{|c|c|c|c|c|c|c|c|c|c|c|}
\hline \multicolumn{11}{|c|}{ DAFIARUAST PLRIIITAGA } \\
\hline $\mathrm{Sa}$ & Tattal & Nabial Mis & Nibi Landa & Operator & Nhaip. & Po & 4 & $W_{q}$ & w & $t$ \\
\hline$T$ & Toesdry, 4 Mdy, 2017 & 20 & 50 & 3 & 0,8333 & 0,1667 & 13,0177 & 0,2804 & 0,3104 & 15,52 \\
\hline$\frac{1}{2}$ & Mendy, 3, Suly,2017 & 27 & 11 & 3 & o,sin & 0,2518 & 1109 & 0,410 & 0,0017 & 13,549 \\
\hline 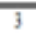 & Mendry, 3Mdy, 2017 & 24 & 33 & 3 & 0,4513 & 0,3477 & 0,3606 & 0,0111 & 0,058 & 1,7424 \\
\hline 4 & 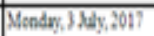 & 16 & If & 3 & 0,997 & 0,2083 & F, $A B Q$ & 0.2213 & 0.295 & $10.86 \%$ \\
\hline 3 & Toutdry, 4Xy, 2017 & 25 & 39 & $\overline{3}$ & 0,787 & 0,2133 & $8,0 \times 5$ & 0,196 & $0.17 \times$ & 10,437 \\
\hline 6 & 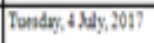 & 15 & 30 & 3 & 0,8669 & 0,03313 & 2.6611 & 0,00 & $0.15 \% 6$ & 4,665 \\
\hline 7 & Tutedry, 4 4 dy, 2017 & 18 & 10 & 7 & 0,1852 & 0,8148 & 0,0665 & 0,0006 & 0,050 & 0,562 \\
\hline
\end{tabular}

Gambar 6. Tampilan Hasil Perhitungan 


\subsection{Pembahasan}

Adapun flowchart algoritma antrian multi channel single phase adalah sebagai berikut:

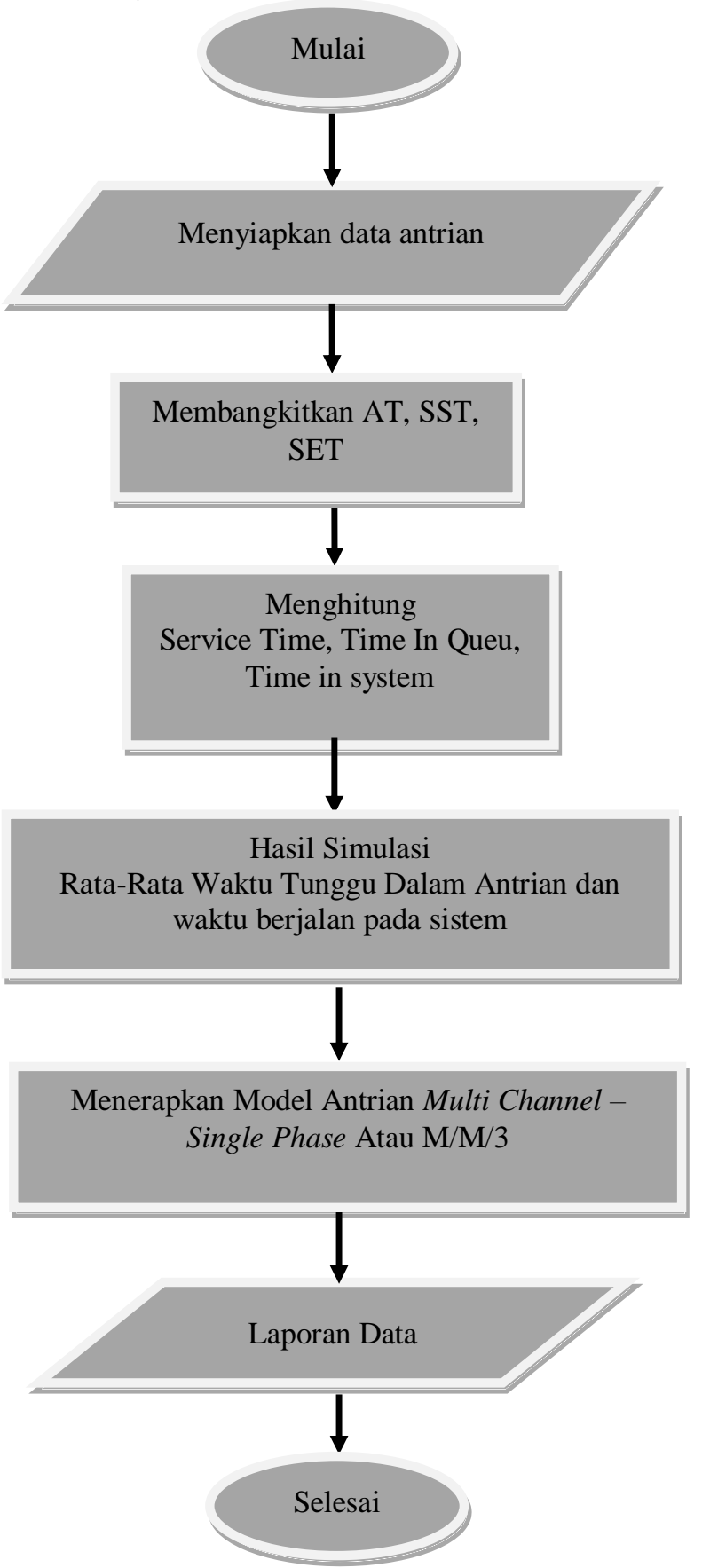

\section{Gambar 7. Flowchart Proses Antrian Multi Channel Single Phase}

\section{Menyiapkan Data Antrian}

Data didapatkan dari operator pelayanan rekam medis pada rumah sakit yang terdiridari beberapa operator dalam proses pelaksanaan pemeriksaan dan perawatan pasien oleh dokter atau instansi rumah sakit.

\section{Membangkitkan AT, SST dan SET}

Data yang telah didapat pada observasi lapangan diinputkan kedalam sistem yaitu data awal mula kedatangan pasien, kemudian waktu dimana pasien mendapatkan pelayanan, setelah itu bangkitkan data waktu pasien selesai mendapatkan pelayanan. 


\section{Menghitung ST, TIQ dan TIS}

Menghitung nilai ST, TIQ dan TIS adalah dengan cara :

ST (Service Time): SET - SST (Service End Time - Service Start Time)

TIQ (Time in Queue): SST - AT (Service Start Time - Arrival Time)

TIS (Time in System): SET - AT (Service End Time - Arrival Time)

Tabel 3. Perhitungan ST, TIQ dan TIS

\begin{tabular}{cccccccc}
\hline No & $\begin{array}{c}\text { Tanggal } \\
\text { Daftar }\end{array}$ & AT & SST & SET & ST & TIQ & TIS \\
\hline $\mathbf{1}$ & $03-07-2017$ & $09: 00$ & $09: 00$ & $09: 10$ & $00: 10$ & $00: 00$ & $00: 10$ \\
\hline $\mathbf{2}$ & $03-07-2017$ & $09: 00$ & $09: 04$ & $09: 15$ & $00: 11$ & $00: 04$ & $00: 15$ \\
\hline $\mathbf{3}$ & $03-07-2017$ & $09: 01$ & $09: 15$ & $09: 25$ & $00: 10$ & $00: 14$ & $00: 24$ \\
\hline $\mathbf{4}$ & $03-07-2017$ & $09: 01$ & $09: 18$ & $09: 28$ & $00: 10$ & $00: 17$ & $00: 27$ \\
\hline $\mathbf{5}$ & $03-07-2017$ & $09: 01$ & $09: 20$ & $09: 30$ & $00: 10$ & $00: 19$ & $00: 29$ \\
\hline $\mathbf{6}$ & $03-07-2017$ & $09: 02$ & $09: 24$ & $09: 35$ & $00: 11$ & $00: 22$ & $00: 33$ \\
\hline $\mathbf{7}$ & $03-07-2017$ & $09: 02$ & $09: 26$ & $09: 36$ & $00: 10$ & $00: 24$ & $00: 34$ \\
\hline $\mathbf{8}$ & $03-07-2017$ & $09: 02$ & $09: 29$ & $09: 40$ & $00: 11$ & $00: 27$ & $00: 38$ \\
\hline $\mathbf{9}$ & $03-07-2017$ & $09: 03$ & $09: 31$ & $09: 41$ & $00: 10$ & $00: 28$ & $00: 38$ \\
\hline $\mathbf{1 0}$ & $03-07-2017$ & $09: 03$ & $09: 44$ & $09: 55$ & $00: 11$ & $00: 41$ & $00: 52$ \\
\hline $\mathbf{1 1}$ & $03-07-2017$ & $09: 04$ & $09: 48$ & $09: 59$ & $00: 11$ & $00: 44$ & $00: 55$ \\
\hline $\mathbf{1 2}$ & $03-07-2017$ & $09: 04$ & $10: 00$ & $10: 11$ & $00: 11$ & $00: 56$ & $01: 07$ \\
\hline $\mathbf{1 3}$ & $03-07-2017$ & $09: 05$ & $10: 01$ & $10: 13$ & $00: 12$ & $00: 56$ & $01: 08$ \\
\hline $\mathbf{1 4}$ & $03-07-2017$ & $09: 05$ & $10: 03$ & $10: 14$ & $00: 11$ & $00: 58$ & $01: 09$ \\
\hline $\mathbf{1 5}$ & $03-07-2017$ & $09: 05$ & $10: 08$ & $10: 15$ & $00: 07$ & $01: 03$ & $01: 10$ \\
\hline $\mathbf{1 6}$ & $03-07-2017$ & $09: 06$ & $10: 10$ & $10: 16$ & $00: 06$ & $01: 04$ & $01: 10$ \\
\hline $\mathbf{1 7}$ & $03-07-2017$ & $09: 06$ & $10: 13$ & $10: 20$ & $00: 07$ & $01: 07$ & $01: 14$ \\
\hline $\mathbf{1 8}$ & $03-07-2017$ & $09: 07$ & $10: 19$ & $10: 32$ & $00: 13$ & $01: 12$ & $01: 25$ \\
\hline $\mathbf{1 9}$ & $03-07-2017$ & $09: 10$ & $10: 21$ & $10: 32$ & $00: 11$ & $01: 11$ & $01: 22$ \\
\hline & & & & & & & \\
\hline
\end{tabular}

\section{Hasil Simulasi Rata-Rata Waktu Tunggu Dalam Antrian dan Waktu Berjalan Pada Sistem}

Dari pengolahan data yang dilakukan, maka dapat dilakukan perhitungan untuk mengetahui waktu rata-rata pasien menunggu dalam antrian yaitu (20436:261=78,3 menit) dan perhitungan untuk mengetahui waktu yang berjalan pada sistem yaitu $(2470: 261=10,5$ menit).

\section{Menerapkan Model Antrian Multi Channel Single Phase atau $M / M / 3$}

Dalam penelitian ini penulis dapat menganalisa dangen menggunakan model antrian multi channel single phase atau $\mathrm{m} / \mathrm{m} / 3$ dengan kinerja sistem antrian yang ada.

$\lambda=$ Tingkat kedatangan rata-rata persatuan waktu

$\mu=$ Tingkat pelayanan rata-rata persatuan waktu

Hari Senin Tanggal 03 Juli 2017 jam $09.00-09.59$ diketahui $\lambda=27 \mu=11 S=3$

a) Tingkat intensitas fasilitas pelayanan $\rho=\frac{\Lambda}{m}=\frac{2 Z}{m-x \rightarrow}=0,8182$

b) Probabilitas terdapat 0 orang dalam sistem

$\mathrm{P} 0=1-\mathrm{P} \times 60$ menit $=(1-0,8182) \times 60=0,1812 \times 60=10,54$ menit

c) Jumlah rata - rata pasien dalam system

$\mathrm{Ls}=\lambda \times \mathrm{X}=27 \times 0,5016=13,54$ atau 14 pasien 
d) Jumlah rata - rata pasien dalam antrian

$$
\mathrm{Lq}=\frac{P o\left(\frac{\lambda}{\mu}\right)^{S}{ }_{P}}{S !(1-P)^{2}}=\frac{0,1812 x\left(\frac{27}{11}\right)^{3} \times 0,8182}{3 !(1-0,8182)^{2}}=11,09 \text { atau } 11 \text { pasien }
$$

e) Waktu pasien berada dalam system

$\mathrm{Ws}=\mathrm{Wq}+\frac{1}{\mu}=0,4107+1 / 11=0,4107+0,0909=0,5016 \times 60$ menit=30,10 menit

f) Waktu pasien berada dalam antrian

$\mathrm{Wq}=\mathrm{Lq} / \lambda=11,09 / 27=0,4107 \times 60$ menit $=24,65$ menit

Hari Senin Tanggal 03 Juli 2017 jam $10.00-10.59$ diketahui $\lambda=38 \mu=16 S=3$

a) Tingkat intensitas fasilitas pelayanan $\rho=\frac{\Lambda}{m}=\frac{3 y}{n \rightarrow a x}=0,7917$

b) Probabilitas terdapat 0 orang dalam sistem

$\mathrm{P} 0=1-\mathrm{P} \times 60$ menit $=(1-0,7917) \times 60=0,2083 \times 60=12,30$ menit

c) Jumlah rata - rata pasien dalam system

$\mathrm{Ls}=\lambda \times \mathrm{x}=38 \times 0,2857=10,85944$ atau 11 pasien

d) Jumlah rata - rata pasien dalam antrian

$\mathrm{Lq}=\frac{P o\left(\frac{\lambda}{\mu}\right)^{S}{ }_{P}}{S !(1-P)^{2}}=\frac{0,2083\left(\frac{38}{16}\right)^{3} \times 0,7917}{3 !(1-0,7917)^{2}}=8,484$ atau 8 pasien

e) Waktu pasien berada dalam system

$\mathrm{Ws}=\mathrm{Wq}+\frac{1}{\mu}=0,2232+1 / 16=0,2232+0,0625=0,2857 \times 60$ menit $=17,15$ menit.

f) Waktu pasien berada dalam antrian

$\mathrm{Wq}=\mathrm{Lq} / \lambda=8,484 / 38=0,2232 \times 60$ menit $=13,40$ menit

Hari Senin Tanggal 03 Juli 2017 jam $11.00-11.59$ diketahui $\lambda=33 \mu=24 S=3$

a) Tingkat intensitas fasilitas pelayanan $\rho=\frac{\Lambda}{m}=\frac{33}{m \sim a}=0,4583$

b) Probabilitas terdapat 0 orang dalam sistem

$\mathrm{P} 0=1-\mathrm{P} \times 60$ menit $=(1-0,4583) \times 60=0,5417 \times 60=32,30$ menit

c) Jumlah rata - rata pasien dalam system

$\mathrm{Ls}=\lambda \times \mathrm{W}=33 \times 0,05277=1,7416$ atau 2 pasien

d) Jumlah rata - rata pasien dalam antrian

$\mathrm{Lq}=\frac{P o\left(\frac{\lambda}{\mu}\right)^{S}{ }_{P}}{S !(1-P)^{2}}=\frac{0,5417\left(\frac{33}{24}\right)^{3} \times 0,4583}{3 !(1-0,4583)^{2}}=0,3661$ atau 1 pasien

e) Waktu pasien berada dalam system

$\mathrm{Ws}=\mathrm{Wq}+\frac{1}{\mu}=0,0011+1 / 24=0,0011+0,0416=0,05277 \times 60$ menit $=3,17$ menit.

f) Waktu pasien berada dalam antrian

$\mathrm{Wq}=\mathrm{Lq} / \lambda=0.3661 / 33=0,0011 \times 60$ menit $=0,67$ menit

Hari Selasa Tanggal 04 Juli 2017 jam $09.00-09.59$ diketahui $\lambda=59 \mu=25 \mathrm{~S}=3$

a) Tingkat intensitas fasilitas pelayanan $\rho=\frac{\Lambda}{m}=\frac{b y}{n \pi m}=0,7867$

b) Probabilitas terdapat 0 orang dalam sistem $\mathrm{P} 0=1-\mathrm{P} \times 60$ menit $=(1-0,7867) \times 60=0,2133 \times 60=12,48$ menit

c) Jumlah rata - rata pasien dalam system

$\mathrm{Ls}=\lambda \times \mathrm{X}=59 \times 0,1769=10,4382$ atau 11 pasien 
d) Jumlah rata - rata pasien dalam antrian

$$
\mathrm{Lq}=\frac{P o\left(\frac{\lambda}{\mu}\right)^{S}{ }_{P}}{S !(1-P)^{2}}=\frac{0,2133\left(\frac{59}{25}\right)^{3} \times 0,7867}{3 !(1-0,7867)^{2}}=8,0782 \text { atau } 8 \text { pasien }
$$

e) Waktu pasien berada dalam system

$\mathrm{Ws}=\mathrm{Wq}+\frac{1}{\mu}=0,1369+1 / 25=0,1369+0,04=0,1769 \times 60$ menit $=10,36$ menit.

f) Waktu pasien berada dalam antrian

$\mathrm{Wq}=\mathrm{Lq} / \lambda=8,0782 / 59=0,1369 \times 60$ menit $=8,12$ menit

\section{Hari Selasa Tanggal 04 Juli 2017 jam $10.00-10.59$ diketahui $\lambda=30 \mu=15 S=3$}

a) Tingkat intensitas fasilitas pelayanan

$$
\rho=\frac{\mu}{m}=\frac{30}{n \rightarrow x=}=0,6667
$$

b) Probabilitas terdapat 0 orang dalam sistem

$\mathrm{P} 0=1-\mathrm{P} \times 60$ menit $=(1-0,6667) \times 60=0,3333 \times 60=20$ menit

c) Jumlah rata - rata pasien dalam system

$$
\mathrm{Ls}=\lambda \times \mathrm{X}=30 \times 0,1555=4,6667 \text { atau } 5 \text { pasien }
$$

d) Jumlah rata - rata pasien dalam antrian

$$
\mathrm{Lq}=\frac{P o\left(\frac{\lambda}{\mu}\right)^{S} \cdot P}{S !(1-P)^{2}}=\frac{0,3333\left(\frac{30}{15}\right)^{3} \times 0,6667}{3 !(1-0,6667)^{2}}=2,6667 \text { atau } 3 \text { pasien }
$$

e) Waktu pasien berada dalam system

$$
\mathrm{Ws}=\mathrm{Wq}+\frac{1}{\mu}=0,0889+1 / 15=0,0889+0,066667=0,1555 \times 60 \text { menit=9,18 menit. }
$$

f) Waktu pasien berada dalam antrian

$\mathrm{Wq}=\mathrm{Lq} / \lambda=2,6667 / 30=0,0889 \times 60$ menit $=5,15$ menit

\section{KESIMPULAN}

Hasil penelitian dapat disimpulkan bahwa dengan metode multi channel pola poisson berhasil dirancang program perhitungan, mampu menjawab permasalahan dan memberikan penanganan serta hasil coba yang didukung dengan perangkat lunak visual basic memperoleh keakuratan hingga 97\%. Prediksi keakuratan yang cukup tinggi pada sistem antrian pendaftaran rekam medis pasien dirumah sakit dapat membantu pihak manajemen rumah sakit dalam menentukan penambahan loket pengambilan obat pada tahun berikutnya.

\section{REFERENCES}

Carvalho, A., and Belo, O. 2016. "Predicting waiting time in customer queuing systems". 2016 IEEE international conference on knowledge engineering and applications, ICKEA 2016,155-159. https://doi.org/10.1109/ICKEA.2016.7803010.

Eni, N., and Utami, I. T. 2016. "Analisis antrian dengan model single channel single phase service pada stasiun pengisian bahan bakar umum (spbu) i gusti”. Jurnal jukanti (JKI), 12(2) : 125-138.

Jaber., and Hussein, A. 2015. "Performance study of Active Queue Management methods: Adaptive GRED, REDD, and GRED-Linear analytical model". Journal Of King Saud University-Computer And Information Sciences. 27 : 417.

Lesti, M. D. 2017. "Analisis Efisiensi Waktu Layanan pada Dinas Kependudukan dan Pencatatan Sipil Kota Kediri dengan Multi Channel - Single Phase". Jurnal SimkiEconomic, Vol. 01 No. 07, ISSN : BBBB-BBBB, Tahun 2017. 
Manin, P. A., and Tarantsev, A. A. 2011. "On some regularities in single-channel unclosed systems with two-phase service". Journal Of Computer And Systems Sciences International. 50(3), 438-447. https://doi.org/10.1134/S1064230711030117

Nengsih, Y. G. (2020). Optimalisasi Antrian Menggunakan Metode Single Channel Single Phase (Studi Kasus DR . Reksodiwiryo Padang). Jurnal Ilmiah Perekam Dan Informasi Kesehatan, 5(1), 30-39. http://jurnal.uimedan.ac.id/index.php/JIPIKI/article/view/356/341

Pughat, A., and Sharma, V. 2015. "Queue discipline analysis for dynamic power management in wireless sensor node". 2015 annual ieee india conference (INDICON), 1-5. https://doi.org/10.1109/INDICON.2015.7443670

Rahayu, U. S., Wasono, R., and Utami, T. W. 2016. "Analisis Sistem Antrian Model Multi Phase-Multi Channel Pada Sentra Pelayanan Kios 3 in 1 Bbplk Semarang”. seminar nasional pendidikan, sains dan teknologi fakultas matematika dan ilmu pengetahuan alam universitas muhammadiyah semarang, 323-330.

Shang, Y. H., Luo, H., and Yu, F. X. 2012. "A phase calibration method for single channel monopulse tracking systems based on curve fitting technique". Proceedings Of The 2012 2nd International Conference On Instrumentation And Measurement, Computer, Communication And Control, IMCCC2012. https://doi.org/10.1109/IMCCC.2012.142

Simanjuntak, E. (2016). Pengaruh Waktu Tunggu Petugas Pelayanan Rekam Medis Terhadap Kepuasan Pasien Di Pendaftaran Rawat Jalan Di Rsud . Dr . R . M . Djoelham Binjai Tahun 2015. Jurnal Ilmiah Perekam Dan Informasi Kesehatan Imelda, 1(1), 35-38. http://jurnal.uimedan.ac.id/index.php/JIPIKI/article/view/7/6.

Simanjuntak, M. (2016). Tinjauan faktor - faktor yang mempengaruhi waktu tunggu Pelayanan Rekam Medis Di Pendaftaran Rawat Jalan Di RSUD. Dr. R. M. Djoelham Binjai Tahun 2015. Jurnal Ilmiah Perekam Dan Informasi Kesehatan Imelda, 1(1), 21-28. http://jurnal.uimedan.ac.id/index.php/JIPIKI/article/view/356/341.

Vorakulpipat, C. 2015. "From Hospital To Patient's Hand: Aself-Service Device For Checking Patient Status Information Using Big Data Analysis”. 476-479.

Wresni, A., and Hendri. 2014. "Simulasi model antrian multiple channel single phase pada sistem pelayanan kasir first come first serve (studi kasus : giant hypermarket panam pekanbaru)". Seminar Nasional IENACO - 2014, ISSN: 2337-4349.

Xing, W., Li, S., and He, L. 2015. "Simulation Model Of Supermarket Queuing System". 2015: 8819 .

Yong, H. S., Hao, L., and Fa,X. Y. 2012. "A Phase Calibration Method For Single Channel Monopulse Tracking Systems Based On Curve Fitting Technique”. 2012 : 577. 


\section{BIOGRAPHIES OF AUTHORS}

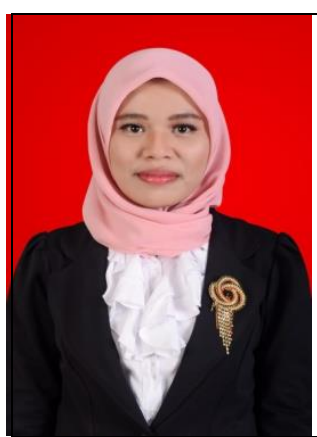

Yeyi Gusla Nengsih, Gelar Sarjana diperoleh dari Universitas Putra Indonesia YPTK Padang, Jurusan Ilmu Komputer pada Tahun 2017. Magister Ilmu Komputer diperoleh dari Universitas Putra Indonesia YPTK Padang pada Tahun 2018. Saat ini aktif sebagai pengajar di Program Studi D-III Perekam dan Informasi Kesehatan Universitas Imelda Medan. 